\title{
SCIDiC
}

\author{
International Journal of Dentistry and Oral Science (IJDOS) \\ ISSN: $2377-8075$
}

\section{Position And Symmetry Of Mental Foramen In Orthopantomogram (OPG) - A Retrospective Observational Study}

Research Article

Srijan Sunar ${ }^{1}$, Archana Santhanam ${ }^{2 *}$, SS Raj ${ }^{3}$

${ }^{1}$ Saveetha Dental College and Hospitals, Saveetha Institute of Medical and Technical Sciences (SIMATS), Saveetha University, Chennai, India.

${ }^{2}$ Assistant Professor, Department of Oral Pathology, Saveetha Dental College and Hospitals, Saveetha Institute of Medical and Technical Sciences (SIMATS), Saveetha University, Chennai, India.

${ }^{3}$ Assistant Professor, Department of Public Health Dentistry, Saveetha Dental College and Hospitals, Saveetha Institute of Medical and Technical Sciences (SIMATS), Saveetha University, Chennai, India.

\section{Abstract}

\begin{abstract}
Mandible is one of the unique bones and is the only movable component of mastication. Mental foramen is a small round/ oval structure present in the mandible. Determining the position of is important for both diagnostic and clinical procedure. The aim of the current study is to analyse the position and symmetry of mental foramen in orthopantomogram (OPG).This is a retrospective clinical study carried out at Private dental institution. This study involves the analysis of orthopantomogram (OPGs) that were taken over a period of one year, from June 2019 to March 2000. A total of 500 OPGs were reviewed and retrieved and the position and symmetry of mental foramen (right and left) were examined. The collected data were subsequently analysed in SPSS with $\mathrm{p}<0.05$ as statistically significant. In this study, position of mental foramen in both males and females was found to be between the first and second premolar for both male and female.The mental foramen was mostly found to be asymmetrical for both male and female ( $68.29 \%$ and $56.61 \%$ respectively), p value $0.08>0.05$, negative correlation. Thus identification of the mental foramen is important for both diagnostic and clinical procedures.
\end{abstract}

Keywords: Mental Foramen; Position; Symmetry; Orthopantomogram.

\section{Introduction}

Mental foramen is a small round/oval structure present in the body of the mandible $[30,28]$ It is a small foramen situated in the anterolateral aspect of the body of the mandible [7]. It opens in a posterior direction and the mental nerve and vessels supplying sensation to the lower lip and the labial mucosa traverses via the mental foramen [8]. The foramen is contained entirely within the buccal cortical plate of bone [34].

Studying the position and morphological variations of mental foramen is important because it is a critical and distinctive landmark for localising the neuromuscular bundle passing through it. Human jaws have shrunk from its large ape size to a smaller one with evolution. Therefore, the third molars are most often impacted which may lead to various complications. Oral squamous cell car- cinoma (OSCC) is the major form of oral cancer and the sixth common malignancy in the world. Due to habits like areca nut chewing there is a high chance of oral squamous cell carcinoma formation. $\mathrm{mdm}-2$ participates in the autoregulation of $\mathrm{p} 53$ function $[13,17,24,25,27,32,33]$. The accurate identification of the mental foramen is important for both diagnostic and clinical procedures $[3,14,35]$. The knowledge of the position of the mental foramen is very important while administering local anaesthesia. Anaesthesia of these nerve could be effective only if the dental practitioners adequately locate the mental foramen. [17, 31, 36]. Lack of knowledge regarding the correct position of mental foramen leads to repeated failure during injections and operation procedures $[5,12,21,22]$.

The knowledge of the mental foramen also plays an important role in endodontic procedure, especially those involving the premolars, fractures related to the parasymphysis region of the man-

*Corresponding Author:

Dr. Archana Santhanam,

Assistant Professor, Department of Oral Pathology, Saveetha Dental College and Hospitals, Saveetha Institute of Medical and Technical Sciences (SIMATS), Saveetha University, Chennai, India.

E-mail: drarch.s@gmail.com

Received: August 17, 2020

Accepted: August 27, 2020

Published: August 30, 2020

Citation: Srijan Sunar, Archana Santhanam, SS Raj. Position And Symmetry Of Mental Foramen In Orthopantomogram (OPG) - A Retrospective Observational Study. Int J Dentistry Oral Sci. 2020;S4:02:0022:112-115. doi: http://dx.doi.org/10.19070/2377-8075-SI02-040022

Copyright: Archana Santhanam ${ }^{\circ} 2020$. This is an open-access article distributed under the terms of the Creative Commons Attribution License, which permits unrestricted use, distribution and reproduction in any medium, provided the original author and source are credited. 
dible, mandibular implant placement and construction of complete denture in the mandible [15-17].

Invasion of squamous cell carcinoma to the mandible can progress through the residual alveolar occlusal ridge $[9,29]$. The radiographic appearance of the mental foramen could also lead to misdiagnosis of a radiolucent lesion such as osteolytic lesions in oral squamous cell carcinoma radiographically $[1,4,11]$. Also in addition to it there is a considerable variation in the shape, position of mental foramen. Literature evidence also supports the fact about presence of accessory foramen or complete absence in few cases. The aim of the current study is to analyse the position and symmetry of mental foramen in orthopantomogram (OPG).

\section{Materials and Methods}

This is a University hospital based retrospective clinical study, carried out at Private Dental Institution, Chennai. Ethical Approval was obtained from the Institutional Review Board.

Study setting: This study involves the analysis of orthopantomogram (OPGs) that were taken over a period of one year, from June 2019 to March 2020. A total of 500 OPGs were collected and assessed for age, gender, position of mental foramen (right and left) and symmetry of mental foramen. Collected data was tabulated in the excel sheet. Cross verified by two examiners. Incomplete dental records were excluded from the study. Randomization was done to minimise sampling bias.

\section{Parameters Evaluated:}

- Good quality OPG with respect to angulation and contrast.

- Presence of all mandibular teeth in both quadrant 3 and quadrant 4.

- Radiographs in which the mandibular teeth were absent, presence of caries, RCT or various restoration were eliminated due to associated periapical radiolucency.

The position of the mental foramen on the OPGs were classified as:

Position 1: position of mental foramen anterior to the first premolar

Position 2: location of MF along the long axis of first premolar Position 3: MF situated between the first and second premolar Position 4: MF in line with the second premolar

Position 5: between the second premolar and the first molar Position 6: MF in line with first molar

\section{Statistical Analysis}

The data was imported and transcribed in the statistical analyses package for social sciences version 20 (SPSS) IBM corporation. Independent variables include and gender. Descriptive analyses were applied and frequencies were found for variables. The relationship between dependent and independent variables was determined using Pearson correlation with $\mathrm{P}$ value $<0.05$ was considered statically significant.

\section{Results And Discussion}

A total of 500 patient's OPGs were evaluated in this study. Of the 500 patient's OPGs, 205 were males (41\%) and 295 (59\%) were females (figure 1). From the present study the relative order of frequency of position of mental foramen on the right side was $48.20 \%$ (figure 2). Similarly the prevalence of mental foramen on the left side was $52.00 \%$ (figure 3 ).

From the present study, in males and females, the most common site of mental foramen (right) is between the first and second premolar (49.27\% \& 47.67 respectively) i.e position -3 (figure 4).

Figure 1. Bar graph depicting the frequency of gender distribution. $59 \%$ were females and $41 \%$ were males.

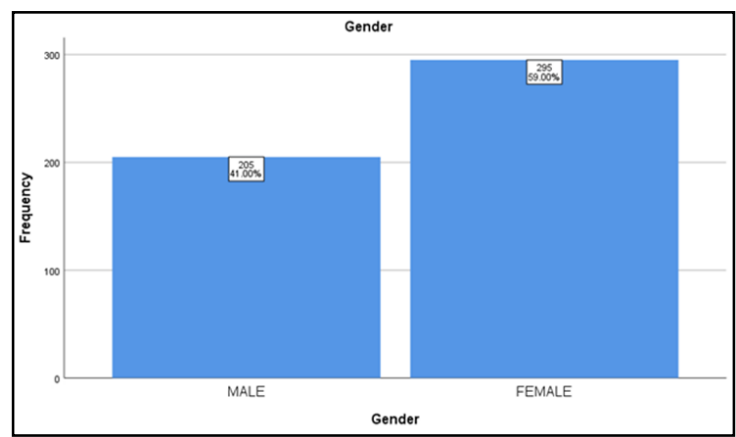

Figure 2. Bar graph shows the frequency of position of mental foramen on the right side. $48.2 \%$ of the study population had mental foramen between first and second premolar.

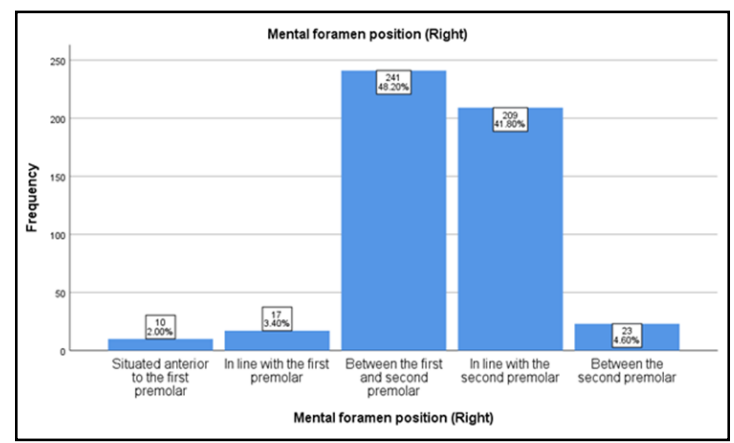


Figure 3. Bar graph shows the frequency of position of mental foramen on the left side. $52 \%$ of the study population had mental foramen between first and second premolar.

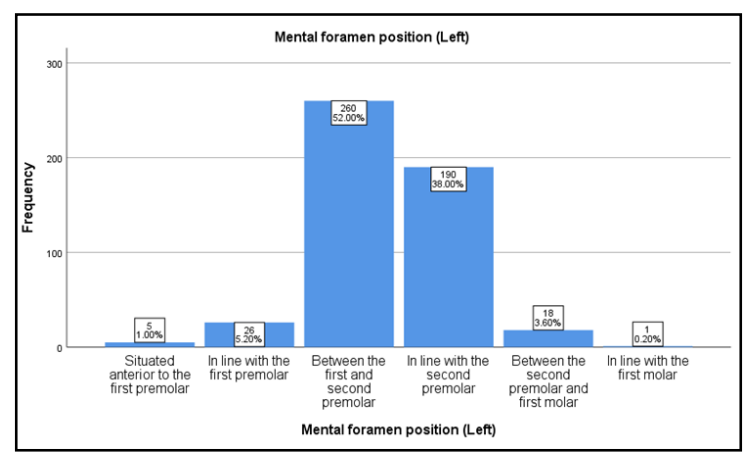

Figure 4. Bar graph shows the association between gender and position of mental foramen on the right side. The most common position of mental foramen in the right side was between the first and second premolar in males was (20.20\%) and in females was $(28.0 \%)$ (green). $P$ value $=0.7>0.05$ statistically not significant using Chi-square test.

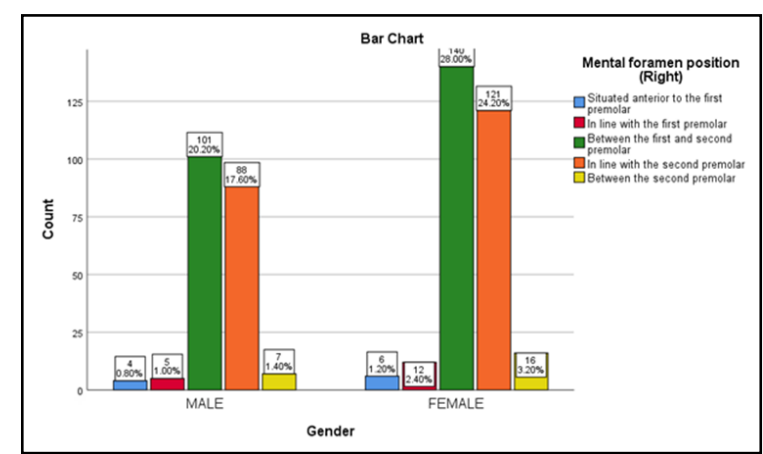

Figure 5. Bar graph shows the gender wise distribution of position of mental foramen on the left side. The most common position of mental foramen in the right side was between the first and second premolar in males was (22\%) and in females was $(30 \%)$ (green). P value $=0.2>0.05$ statistically not significant using Chi-square test.

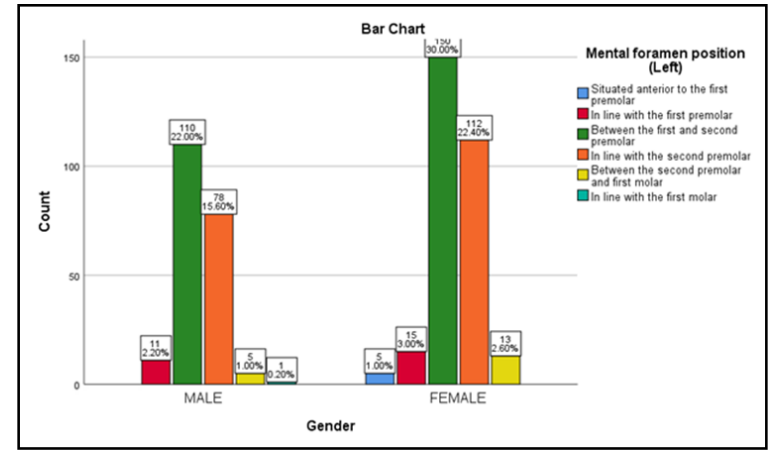

Figure 6. Bar graph shows the gender wise distribution of symmetry of mental foramen. The mental foramen is asymmetrical in both the gender. $P$ value $=0.008>0.05$ statistically significant using Chi-square test.

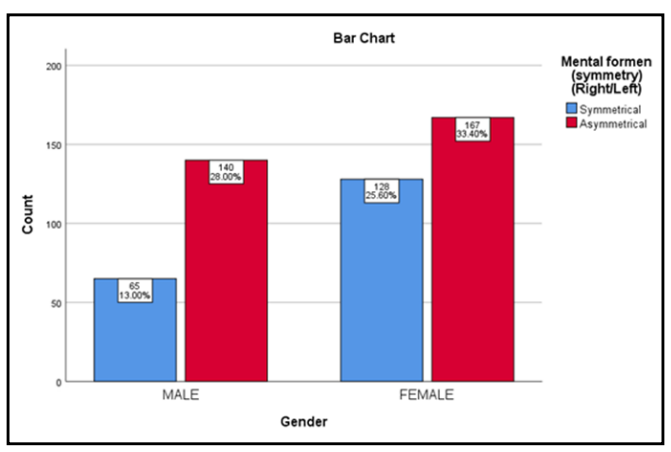

Negative correlation was found between gender and position of mental foramen with $\mathrm{P}$ value $=0.7>0.005$ statistically not significant.

The most common position mental foramen(left) in the present study in males and females were between first and second premo- $\operatorname{lar}(53.6 \%$ \& 50.85\% respectively) i.e position -3 (figure 5). Similar results were in seen in previous literature done by [26] (same evidence-57\%), [10] (same evidence-63\%), [20] (same evidence$40-50 \%)$. This variation is mostly seen due to morphological variation seen in mandibles among different gender, ethnicities and races. Negative correlation was found between gender and 
position of mental foramen with $\mathrm{P}$ value $=0.2>0.05$ statistically not significant.

The mental foramen was asymmetrical in $28 \%$ of males and $33.40 \%$ in females (figure 6) which is consistent with literature by [3] $51.3 \%$, [6] 51.1\%. On contract some previous literature shows most of the individuals have symmetrical mental foramen as in [2]. This variation is mostly seen due to morphological variation seen in the mandible among different gender, ethnicities and races.

The knowledge of mental foramen also plays an important role in various dental treatments and clinical procedure [1, 23]. Limitations of the present study is small sample size and single centered study.

\section{Conclusion}

Variation in the position and symmetry of mental foramen is mostly seen due to morphological variation seen in the mandible among different gender, ethnicities and races. Bearing in mind the limits of the study, the most common site of mental foramen in both right and left is in between the first and second premolar, with most being asymmetrical.

\section{References}

[1]. Alok A, Singh ID, Panat SR, Singh S, Kishore M, Jha A. Position and symmetry of mental foramen: A radiographic study in bareilly population. Journal of Indian Academy of Oral Medicine and Radiology. 2017 Jan 1;29(1):16.

[2]. Al-Shayyab MH, Alsoleihat F, Dar-Odeh NS, Ryalat S, Baqain ZH. The Mental Foramen I: Radiographic Study of the Anterior-Posterior Position and Shape in Iraqi Population. International Journal of Morphology. 2015 Mar 1;33(1).

[3]. Bello SA, Adeoye JA, Ighile N, Ikimi NU. Mental Foramen Size, Position and Symmetry in a Multi-Ethnic, Urban Black Population: Radiographic Evidence. J Oral Maxillofac Res. 2018 Dec 30;9(4):e2.Pubmed PMID: 30746051.

[4]. Bhagat J, Shah D, Fernandes G. Prevalence of the Mental Foramen Location in an Indian Subpopulation: A Retrospective Orthopantomogram Study. Int J Oral Care Res. 2018;6(2):89-92.

[5]. Chakraborty R, Sen S, Panchbhai A, Bhowate RR, Dupare A. Comparison between conventional radiograph and $3 \mathrm{D}$ volumetric radiograph for determining the morphology and morphometry of mental foramen. Journal of Indian Academy of Oral Medicine and Radiology. 2019 Jan 1;31(1):17.

[6]. Cheong YW, Lo LJ. Facial asymmetry: etiology, evaluation, and management. Chang Gung Med J. 2011 Jul-Aug;34(4):341-51. PubmedPMID: 21880188.

[7]. Dave PH, Krishnan M. Gender determination by orthopantomogram analysis of mental foramen in South Indian population-A retrospective study. Drug Invention Today. 2019 Oct 1;11(10).

[8]. D'dharan SR, Maheswari TN. EVALUATION OF POSITION OF MENTAL FORAMEN USING CBCT AMONG CHENNAI POPULATION: A RETROSPECTIVE STUDY. International Journal of Clinical Dentistry. 2015 Oct $1 ; 8(4)$.

[9]. Devi VN, Dhanraj M, Jain AR. Knowledge attitude and practice of dental practitioners in the management of traumatic neuroma-a survey. Drug Invention Today. 2018 Apr 1;10(4).

[10]. Gada SK, Nagda SJ. Assessment of position and bilateral symmetry of occurrence of mental foramen in dentate asian population. J ClinDiagn Res. 2014 Feb;8(2):203-5. PubmedPMID: 24701535.

[11]. Gheena $S$, Ezhilarasan D. Syringic acid triggers reactive oxygen species-mediated cytotoxicity in HepG2 cells. Hum ExpToxicol. 2019 Jun;38(6):694702. PubmedPMID: 30924378.

[12]. Ghimire B, Gupta S. Location of Mental Foramen in Dentate Adults using Orthopantomogram. JNMA J Nepal Med Assoc. 2018 JulAug;56(212):791-795. PubmedPMID: 30387471.

[13]. Gupta V, Ramani P. Histologic and immunohistochemical evaluation of mirror image biopsies in oral squamous cell carcinoma. J Oral BiolCraniofac Res. 2016 Sep-Dec;6(3):194-197. PubmedPMID: 27761383.

[14]. Hannah R, Ramani P, Sherlin HJ, Ranjith G, Ramasubramanian A, Jayaraj
G, et al. Awareness about the use, ethics and scope of dental photography among undergraduate dental students dentist behind the lens. Research Journal of Pharmacy and Technology. 2018 Mar 1;11(3):1012-6.

[15]. Jajashree KA, Senthilnathan KP, Kumar MP. Assessment of Location and Dimensions of Mental Foramen-A CBCT Study. Research Journal of Pharmacy and Technology. 2018;11(8):3486-8.

[16]. Jangid K, Alexander AJ, Jayakumar ND, Varghese S, Ramani P. Ankyloglossia with cleft lip: A rare case report. J Indian SocPeriodontol. 2015 NovDec;19(6):690-3. PubmedPMID: 26941523.

[17]. Jayaraj G, Sherlin HJ, Ramani P, Premkumar P, Anuja N. Cytomegalovirus and Mucoepidermoid carcinoma: A possible causal relationship? A pilot study. J Oral MaxillofacPathol. 2015 Sep-Dec;19(3):319-24. PubmedPMID: 26980959.

[18]. Jayaraj G, Ramani P, Sherlin HJ, Premkumar P, Anuja N. Inter-observer agreement in grading oral epithelial dysplasia-A systematic review. Journal of Oral and Maxillofacial Surgery, Medicine, and Pathology. 2015 Jan $1 ; 27(1): 112-6$

[19]. Jayaraj G, Sherlin HJ, Ramani P, Premkumar P, Natesan A. Stromal myofibroblasts in oral squamous cell carcinoma and potentially malignant disorders. Indian J Cancer. 2015 Jan-Mar;52(1):87-92. PubmedPMID: 26837985.

[20]. Krzeszinski JY, Wei W, Huynh H, Jin Z, Wang X, Chang TC, et al. miR-34a blocks osteoporosis and bone metastasis by inhibiting osteoclastogenesis and Tgif2. Nature. 2014 Aug;512(7515):431-5.

[21]. Kumar A, Sherlin HJ, Ramani P, Natesan A, Premkumar P. Expression of $\mathrm{CD} 68, \mathrm{CD} 45$ and human leukocyte antigen-DR in central and peripheral giant cell granuloma, giant cell tumor of long bones, and tuberculous granuloma: An immunohistochemical study. Indian J Dent Res. 2015 MayJun;26(3):295-303. PubmedPMID: 26275199.

[22]. Renjith G, Mary DP, Soe K, Wan MY, Beh HC, Phuah WH, et al. Sex estimation by discriminant function analysis using anatomical location of mental foramen. Forensic Science International: Reports. 2019 Nov 1;1:100018.

[23]. Sarker S, Roy SP, Chowdhury TG, Rahman D, Hossain MM, Saki N, et al. Evaluation of Radiographic Measurement of Mental Foramen in Selected Urban Population. KYAMC Journal. 2019 May 22;10(1):31-4.

[24]. Shanmugasundaram K, Prasanthi S. Sex Determination using Mental Foramen in Chennai Population. Prof. RK Sharma. 2019 Jan;13(1):63.

[25]. Hema Shree K, Ramani P, Sherlin H, Sukumaran G, Jeyaraj G, Don KR, et al. Saliva as a Diagnostic Tool in Oral Squamous Cell Carcinoma - a Systematic Review with Meta Analysis. PatholOncol Res. 2019 Apr;25(2):447-453. PubmedPMID: 30712193.

[26]. Shukla AK, Kumar R and Jha KK. Position of mental foramen among two North Indian population.2017;3(3):154-155.

[27]. Sivaramakrishnan SM, Ramani P. Study on the Prevalence of Eruption Status of Third Molars in South Indian Population. Biology and Medicine. 2015 Oct 1;7(4):1.

[28]. Sridharan G, Ramani P, Patankar S. Serum metabolomics in oral leukoplakia and oral squamous cell carcinoma. J Cancer Res Ther. 2017 JulSep;13(3):556-561. PubmedPMID: 28862226.

[29]. Sridharan G, Ramani P, Patankar S, Vijayaraghavan R. Evaluation of salivary metabolomics in oral leukoplakia and oral squamous cell carcinoma. J Oral Pathol Med. 2019 Apr;48(4):299-306. PubmedPMID: 30714209.

[30]. Sridhar M, Dhanraj M, Thiyaneswaran N, Jain AR. A retrospective radiographic evaluation of incisive canal and anterior loop of mental nerve using cone beam computed tomography. Drug Invention Today. 2018 Sep $1 ; 10(9)$.

[31]. Sunar S, Thenmozhi MS. A study on the age changes of mandible. Drug Invention Today. 2018 Dec 1;10(12).

[32]. Swathy S, Gheena S, Sri VL. Prevalence of pulp stones in patients with history of cardiac diseases. Research Journal of Pharmacy and Technology. 2015 Dec 1;8(12):1625.

[33]. Thangaraj SV, Shyamsundar V, Krishnamurthy A, Ramani P, Ganesan K, Muthuswami M, et al. Molecular Portrait of Oral Tongue Squamous Cell Carcinoma Shown by Integrative Meta-Analysis of Expression Profiles with Validations. PLoS One. 2016 Jun 9;11(6):e0156582. PubmedPMID: 27280700.

[34]. Umayal S, Mohanraj KG, YuvarajBabu K. Morphological study of accessory foramina in the mandible. Drug Invention Today. 2018 Dec 1;10(12).

[35]. Vasishta PA, Thenmozhi MS, Lakshmanan G. Position and symmetry of mental foramen: A radiographic study in South Indian population. Drug Invention Today. 2019 Jun 15;12(6).

[36]. Viveka TS, Shyamsundar V, Krishnamurthy A, Ramani P, Ramshankar V. p53 Expression Helps Identify High Risk Oral Tongue Pre- malignant Lesions and Correlates with Patterns of Invasive Tumour Front and Tumour Depth in Oral Tongue Squamous Cell Carcinoma Cases. Asian Pac J Cancer Prev. 2016;17(1):189-95. PubmedPMID: 26838208. 